\title{
The nature of the Precambrian-Tertiary boundary at Renardodden, Bellsund, Svalbard
}

\author{
WINFRIED K. DALLMANN
}

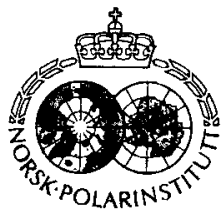

\begin{abstract}
Dallmann, W. K. 1989: The nature of the Precambrian-Tertiary boundary at Renardodden, Bellsund, Svalbard. Polar Research 7, 139-145.

The previous literature on the occurrence of Tertiary strata at Renardodden provides contradictory information about the primary versus tectonic boundary with the Precambrian basement. Tertiary sandstones and shales overlie unconformably the basement rocks, which have been resedimented as boulder conglomerates prior to Caledonian metamorphism and weathered prior to the deposition of the Tertiary strata. The boundary relations are complicated by a repeatedly active fault system that may form part of the Inner Hornsund Fault Zone.
\end{abstract}

Winfried K. Dallmann, Norsk Polarinstitutt, P.O. Box 158, N-1330 Oslo Lufthavn, Norway; June 1989

\section{Geological context}

Rocks of Tertiary age occur south of Bellsund on Calypsostranda, and are well exposed in the coastal cliff between Renardodden and Skilvika (Fig. 1). The occurrence has been described by Atkinson (1963), Vonderbank (1970), Livšic (1974), Kellogg (1975) and Thiedig et al. (1979). The strata are intercalated sandstones and silt- stones with thin layers of bituminous shales and coal seams. They are cumulatively $335 \mathrm{~m}$ thick, and are interpreted as a marginal basin facies with a limnofluvial influence (Thiedig et al. 1979). Their age has been determined by pollen and spores to be Oligocene (Livšic 1974) and by dinocysts to be Late Eocene/Early Oligocene (Head 1984; Manum \& Throndsen 1986).
Fig. 1. Location map and geological setting of the Renardodden area.

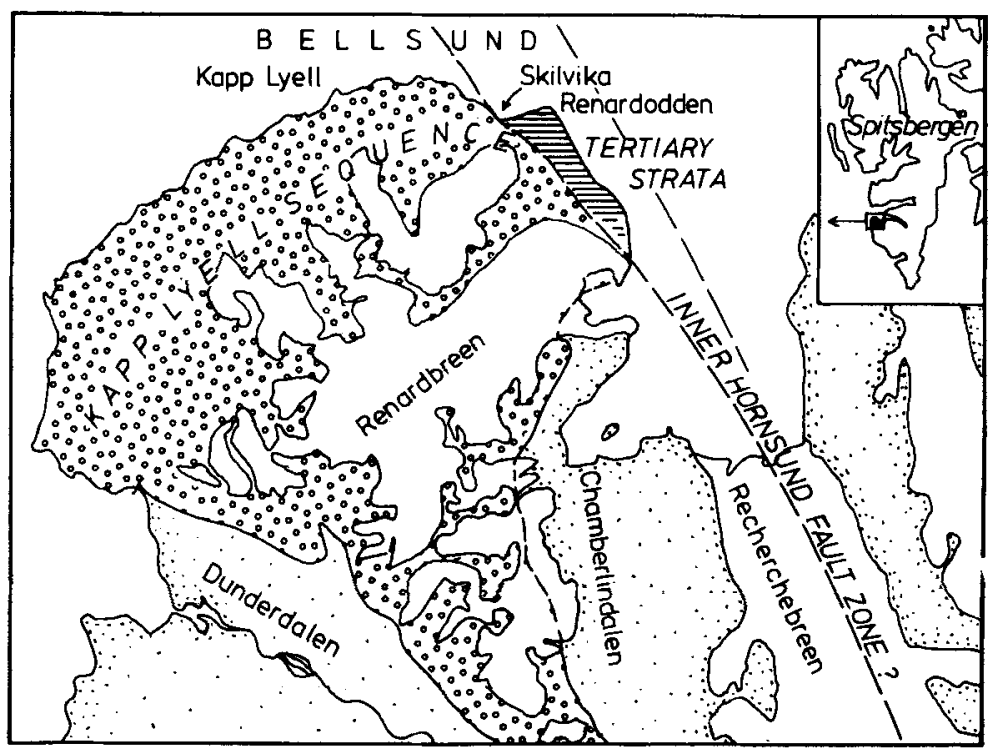


The Tertiary strata occur adjacent to Precambrian basement rocks of Vendian age belonging to the Kapp Lyell sequence consisting of mainly tilloid rocks (Hjelle 1969; Harland 1978; Kowallis 1979; Waddams 1983; Kowallis \& Craddock 1984). This sequence makes up the whole mountain area between Bellsund, Chamberlindalen and Dunderdalen (Fig. 1).

The problem of a primary versus tectonic nature of the boundary between the Vendian and Tertiary rocks or, in other terms, of the existence versus non-existence of a fault between the Kapp Lyell and Renardodden domains is important when interpreting the tectonic evolution of the Bellsund area.

\section{Previous interpretations}

Vonderbank (1970) ascribes a 4-5 m thick basal conglomerate to the Tertiary strata, which rests on a $6 \mathrm{~m}$ thick zone of strongly weathered mica schists belonging to the basement. He mentions that the primary contact and the adjacent beds are tectonized.

Livšic (1974) also mentions a primary contact overlain by a $4.3 \mathrm{~m}$ thick basal conglomerate. His map (appendix 4), however, shows a fault cutting the boundary at a low angle.

Lehmann et al. (1978) describe the Renardodden area as a tectonically isolated occurrence of Tertiary strata, but do not specify the tectonic nature.

Thiedig et al. (1979) state that the Tertiary rocks are separated from the Precambrian by a fault that is well exposed in Skilvika. The 'Precambrian' side of the fault is made up of huge blocks of Precambrian tilloids which, however, seem to lie within an unconsolidated matrix of a 'probably very young age'. The authors suggest it might either reflect a mylonite zone related to the fault or a land slip ('Felsgleitung') of Tertiary age. Northeast of the fault, the Tertiary section starts with a $4-5 \mathrm{~m}$ thick basal conglomerate.

Kowallis (1979) describes the boundary as a fault contact with a zone of brecciated material. Drag along the fault is considered to have caused the increase of dip of the Tertiary strata towards the boundary.

Hauser (1982) suggests a fault contact, although mostly covered, because of the brecciated zone and the observed drag effect.

\section{Description}

The following description is from NW to SE along the coastal cliff, and refers to the sketch map (Fig. 2 and 3 ). Unfortunately, the section is not exposed continuously.

Localities 1-4 represent typical tilloids with quartzite and dolomite clasts and intercalated quartzites of the Kapp Lyell sequence. Localities 2-4 show increasing hematite impregnation towards the east.

The lower part of loc. 5 is a strongly boudined quartzitic tilloid which is strongly fractured. Its metamorphic foliation has approximately the

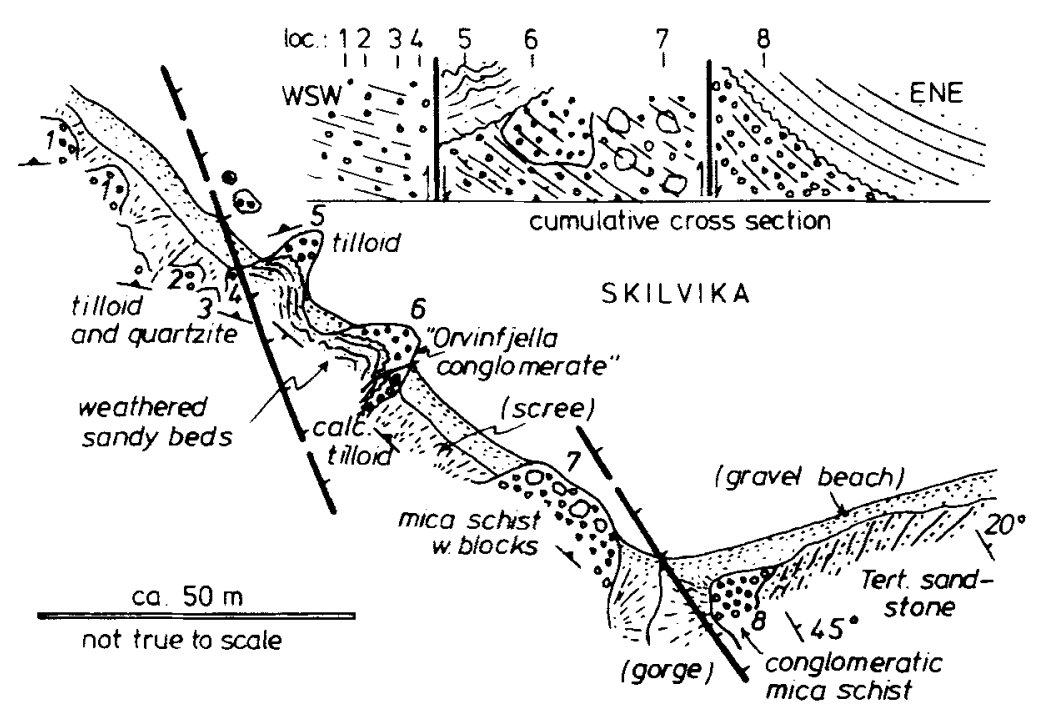

Fig. 2. Sketch map of the Skilvika coastal section. Numbers from 1 to 8 refer to the discussed localities. Explanation in the text. 


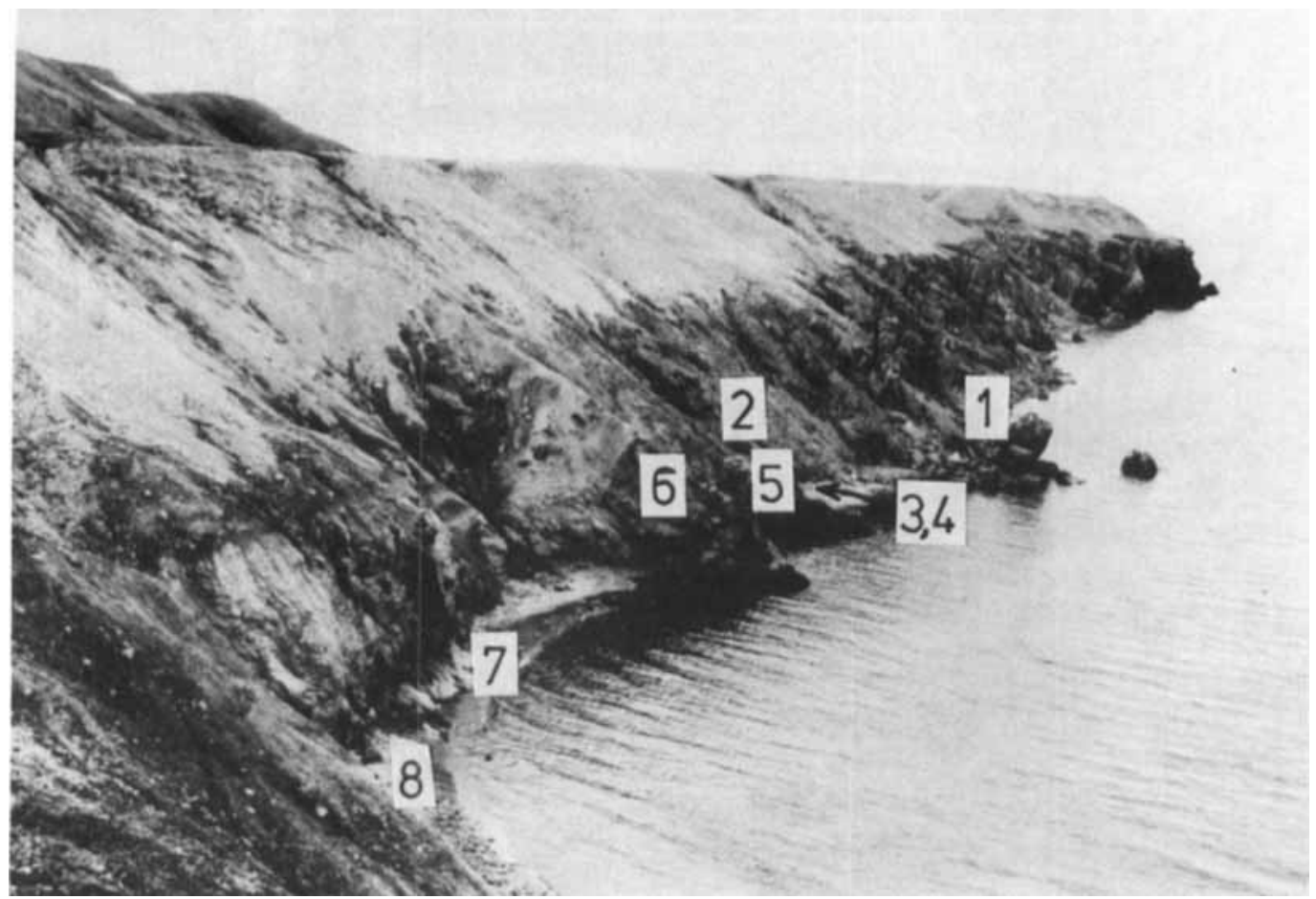

Fig. 3. View of part of the Skilvika coastal section, with inferred localities. Scale: elevation of coastal cliff c. $25 \mathrm{~m}$.

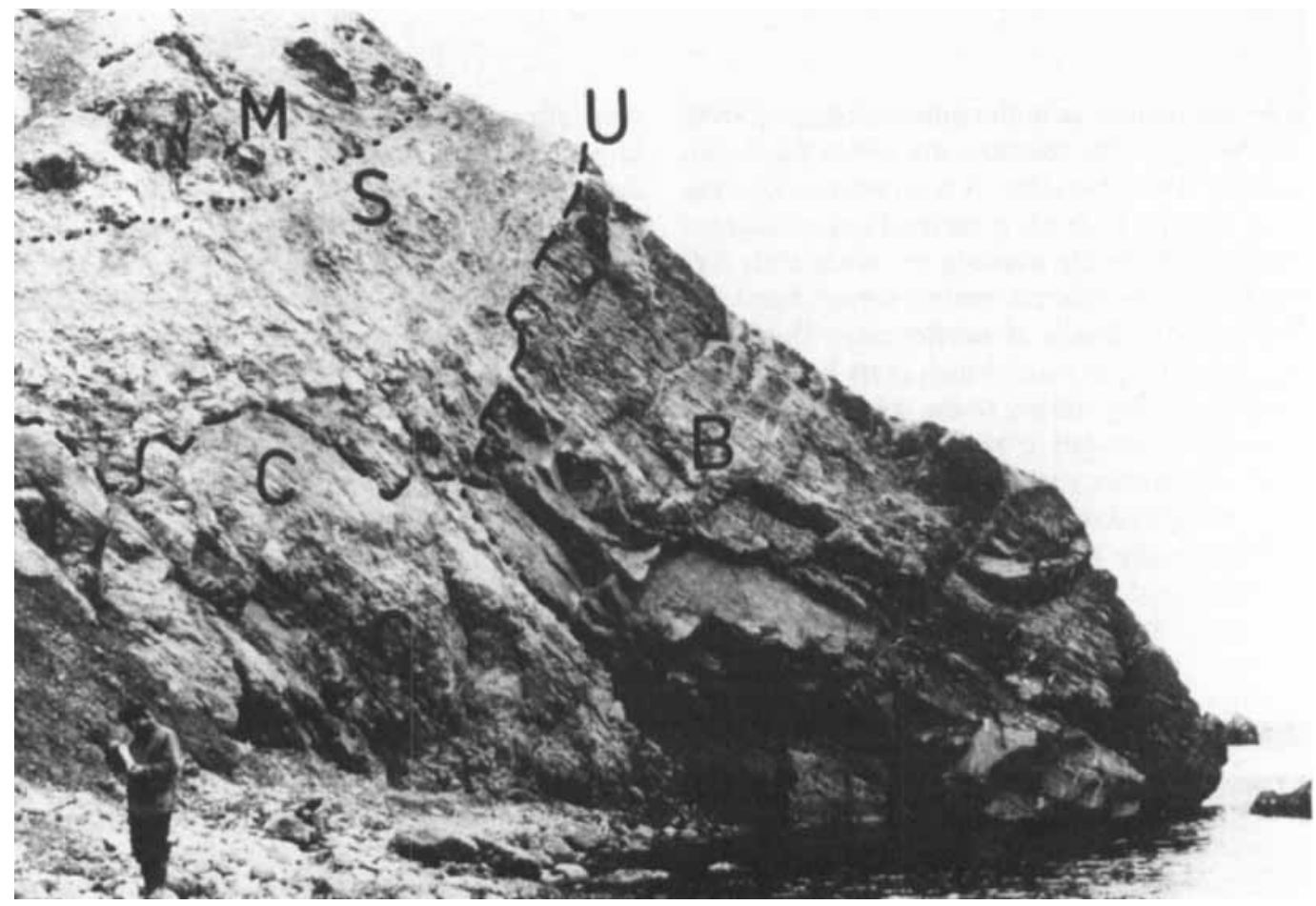

Fig. 4. Locality 6 seen from the SE. B: large block of conglomerate, C: conglomeratic calcareous mica schist, U: unconformity, S: sandy beds above unconformity, M: Pleistocene moraine and scree. 


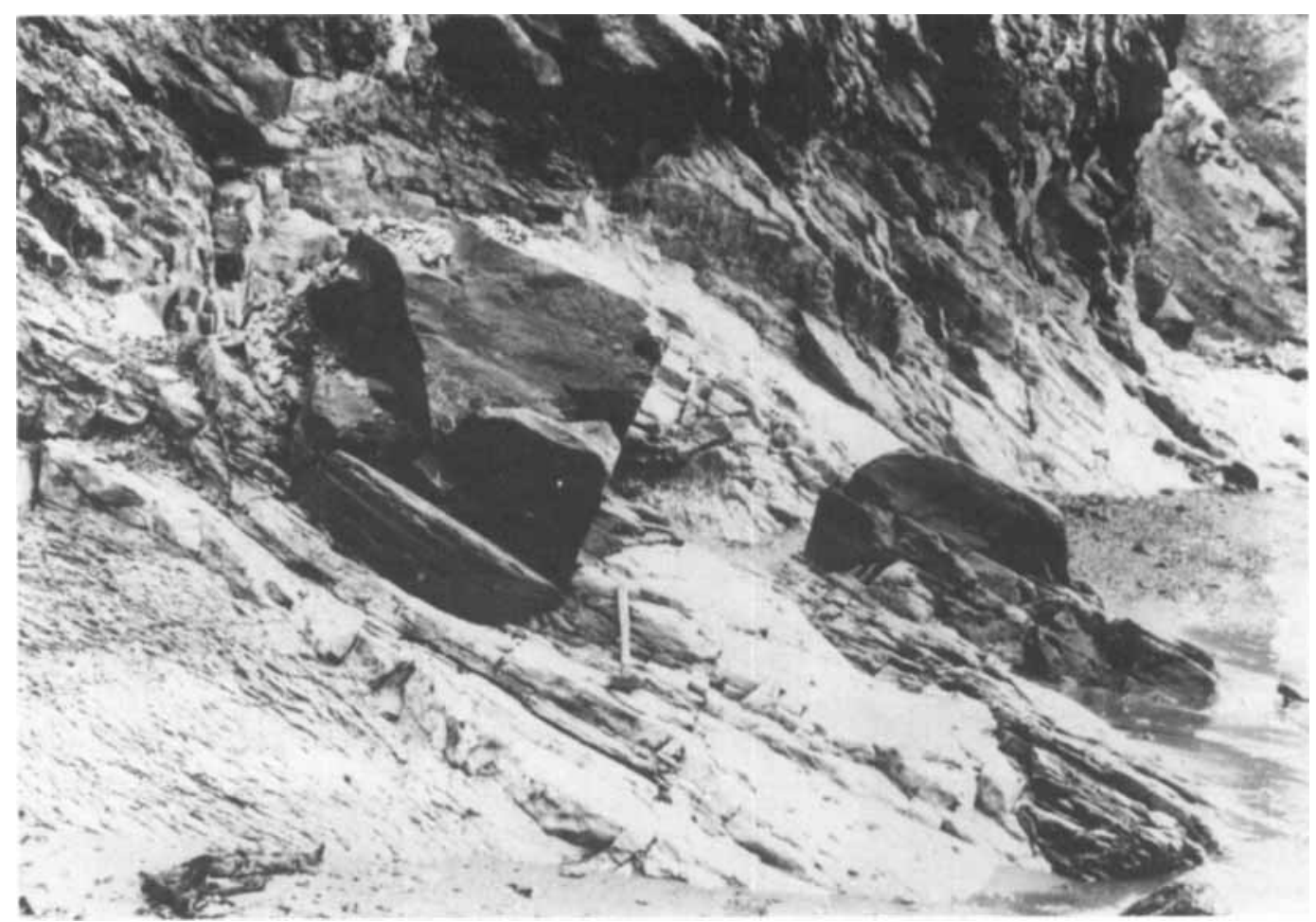

Fig. 5. Locality 7 seen from the SE. Alternating mica schists and psammitic layers with metre-size boulders. The metamorphic foliation in clasts and matrix is conformable.

same orientation as in the other localities (NNW to NNE dip). The fractures are either filled with quartz or Fe-hydroxides. A few metres above the coast line the bedrock is increasingly weathered and unconformably overlain by moderately SW dipping, multicoloured, poorly consolidated but locally folded layers of sand(stone). The sandy material is rich in mica. which at its base defines a weak foliation oblique to the colour layering. It probably represents a residual foliation of the weathered source rock which thus is supposed to have weathered in situ.

These sandy beds are continuously exposed southeastward to loc. 6 (Fig. 4). There, they unconformably overlie a different tilloid lithology, comprised of a huge block similar in lithology to the Orvinfjella conglomerate $(H$. Maher pers. comm. 1988) exposed south of Dunderdalen. This block seems to be embedded within a matrix of tilloid calcareous mica schist. The metamorphic foliations in the matrix and the block are parallel. The primary contact is here cut by a minor fault. However, boundary relations are somewhat uncertain, and the two lithologies may alternatively represent the same primary layer, but with a different degree of paleo-weathering.

In loc. 7 (Fig. 5) the tilloids occur at the shore and in a vertical cliff, and dip gently NE. Here, the rocks are mica schists, partly conglomeratic, interbedded with psammitic layers. They also contain metre-size boulders of more quartz-rich schist or impure quartzite. The foliations in the bedrock and the boulders are parallel, whenever the latter are foliated.

East of the creek, loc. 8 (Fig. 6) starts with moderately ENE dipping conglomeratic mica schists similar to those at loc. 7 . The rocks are increasingly brecciated upward. The uppermost part of this zone is enriched in sulphur indicating reducing redox conditions. This horizon is overlain by homogeneously grey brecciated and weathered material, the $4-5 \mathrm{~m}$ thick 'basal Tertiary conglomerate' of previous authors (Vonderbank 1970; Livšic 1974; Thiedig et al. 1979). Thin sections, however, show that these rocks still represent a metamorphic, though highly weathered lithology with a mostly continuous 


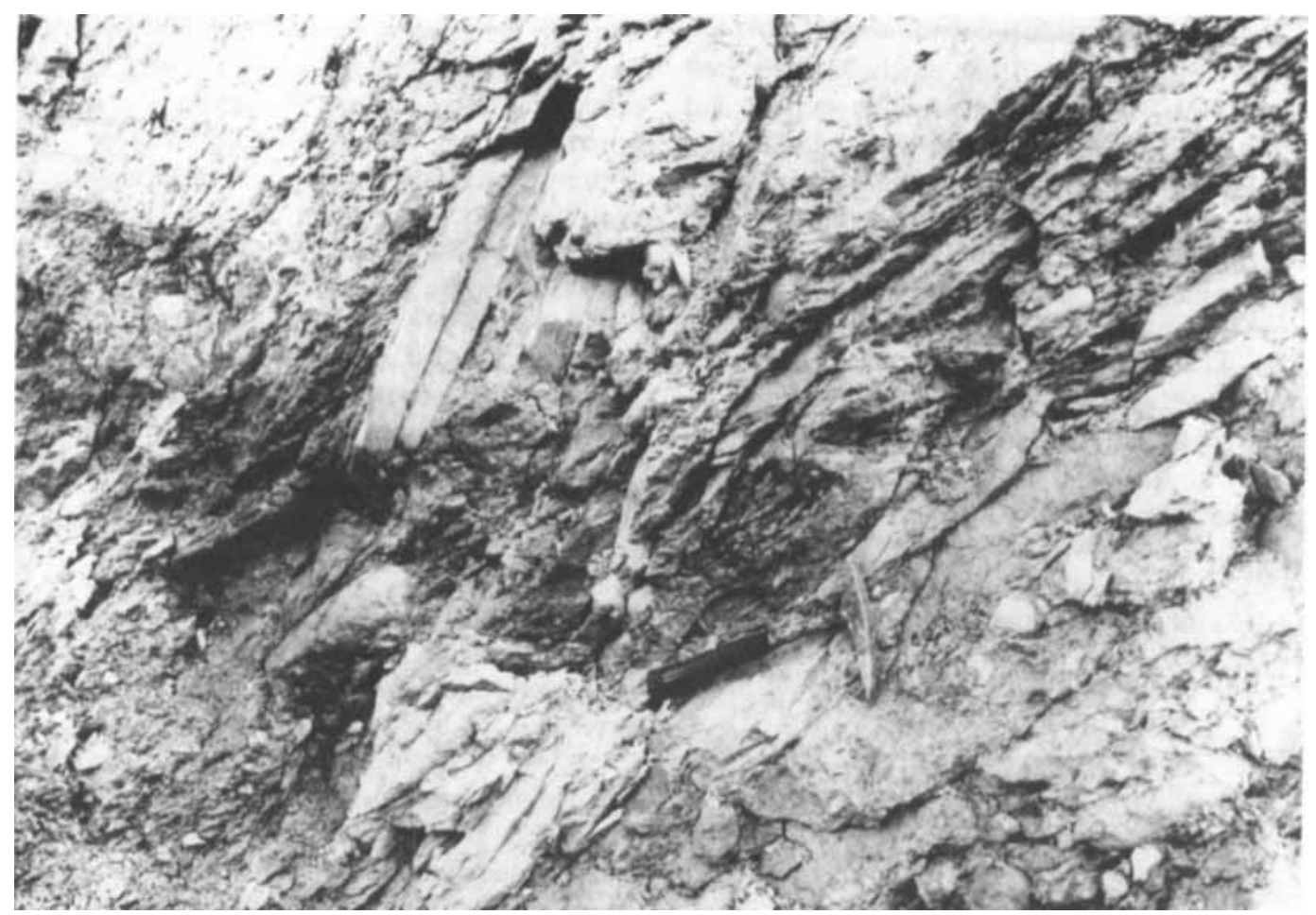

Fig. 6. Locality 8, western part: brecciated conglomeratic mica schist.

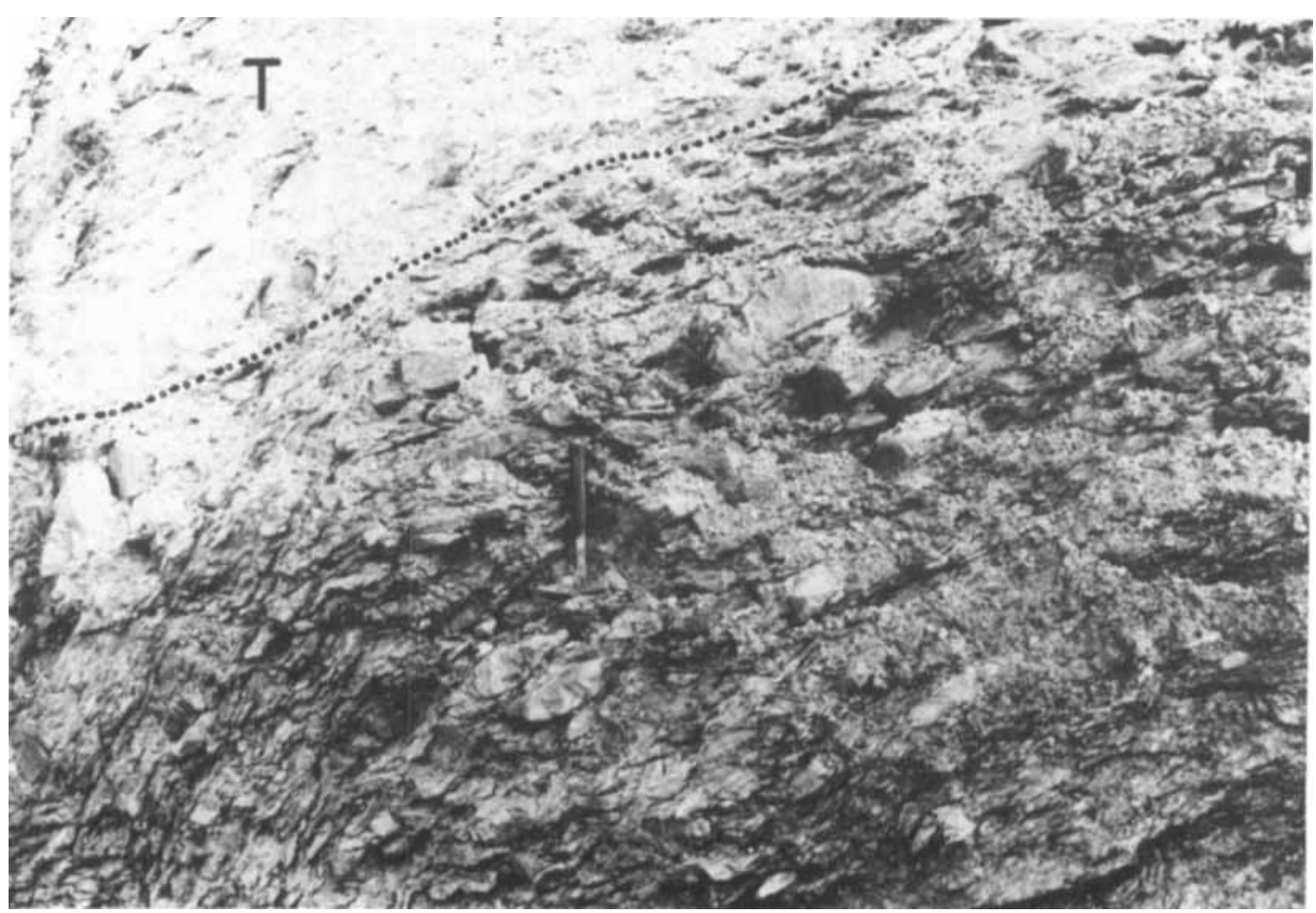

Fig. 7. Locality 8, eastern part: base of the Tertiary sandstone (T) above weathered tilloid basement. 
matrix foliation between the tillitic clasts. Finally, a thin weathering horizon, partly coloured red by Fe-oxides and partly enriched in sulphur and white clay minerals indicating changing redox conditions, forms the base of the Tertiary sandstones (Fig. 7). These are bedded subparallel to the foliation of the tilloids, are very immature, are composed of grains derived from the basement and contain only scattered tilloid clasts. The ENE dip of the Tertiary strata decreases eastward from c. $45^{\circ}$ to $20^{\circ}$ along the exposed section.

Although the angularity of this contact can but poorly be demonstrated in the exposed section, the unconformable nature of the boundary is clearly indicated by the weathered transition zone from a deformed, metamorphic to an almost undeformed, non-metamorphic lithology.

\section{Reinterpretation}

Several conclusions concerning the tectonic history of the area can be drawn from the above observations:

1. Huge blocks (loc. 6) and scattered metresize boulders (loc. 7) are usually not found in the Kapp Lyell sequence. Their local occurrence at Skilvika suggests fault scarp-related sedimentation in either Vendian time or later, but prior to Caledonian metamorphism and foliation development.

2. The sandy beds unconformably overlying the tilloids (loc. 5 and 6) are folded. Their deformation is younger than the Caledonian deformation of the basement. The weathering of the basement must thus be due to post-Caledonian uplift. They may have been at depth again prior to the Early Tertiary tectonic event, as this is the latest event that may have folded them. Alternatively, the weathering may be of Tertiary age and the folds be either sedimentary slump folds or related to later faulting. The folds have not been studied because of difficult access.

3. The orientation of the basement rocks in loc. $1-4$ in relation to loc. 5 and 6 along with the dip of the weathered sandy beds demand a fault offset between loc. 4 and 5 . The fault is younger than the weathering of the basement, and the area - at least the eastern block - has been tilted to the SW after the weathering episode.

4. Another fault is situated somewhere between loc. 5,6 and 8 , because the two weathered sur- faces dip the opposite way. It is improbable that the change of dip is caused by folding, as only extensional tectonics are known from Svalbard from the Eocene-Oligocene boundary (age of the Tertiary strata) onward. The suggested fault lies most probably in the gorge, as there seems to be continuity between loc. 5, 6 and 7 . The fault must have been active at least after deposition of the Tertiary strata to explain the drag effect indicated by the change of dip. The brecciation of the basement rocks in the vicinity of the gorge supports this assumption.

\section{Conclusion}

Although the Tertiary strata rest with a primary contact on the Precambrian basement, the Renardodden domain is separated from the Kapp Lyell domain by a fault system. A multi-stage tectonic history of this structure controlling uplift and sedimentation from pre-Caledonian to Tertiary times is indicated. This suggests that the Renardodden fault is part of a long-lived tectonic lineament, although the age and magnitude of the individual faulting events cannot be determined. This lineament would most probably trend NNWSSE and continue southward below the Recherchebreen glacier (Fig. 1).

A probable candidate is the Inner Hornsund fault zone, which is thought to have controlled Carboniferous through Triassic sedimentation (Steel \& Worsley 1984). According to an alternative tectonic model, the Renardodden fault could be part of the Central-west fault zone (Harland \& Wright 1979) separating the western and central basement provinces of Svalbard.

Acknowledgement. - I am grateful to Harmon D. Maher, Jr. (Omaha) for discussions in the ficld and valuable comments on the manuscript.

\section{References}

Atkinson. D. J. 1963: Tertiary rocks of Spitsbergen. Bulletin American Association of Petroleum Geologists 47, 302-323.

Harland. W. B. 1978: A reconsideration of Late Precambrian stratigfaphy of southern Spitsbergen. Polarforschung 48,44 61.

Harland. W. B. \& Wright, N. J. R. 1979: Alternative hypothesis for the pre-Carboniferous evolution of Svalbard. Norsk Polarinstitut Skrifter 167, 89-117.

Hauser, E. C. 1982: Tectonic evolution of a segment of the West Spitsbergen fold belt in northern WedelJarlsberg Land. Ph.D. thesis. University of Wisconsin-Madison. $188 \mathrm{pp}$. 
Head, M. 1984: A palynological investigation of Tertiary strata at Renardodden, West Spitsbergen. Abstract, 6th International Palynological Conference, Calgary 1984, 61.

Hjelle, A. 1969: Stratigraphic correlation of Hecla Hoek successions north and south of Bellsund. Norsk Polarinstitutt Årbok 1967, 46-51.

Kellogg, H. E. 1975: Tertiary stratigraphy and tectonism in Svalbard and continental drift. Bulletin American Association of Petroleum Geologists 59, 465-485.

Kowallis, B. J. 1979: Structure and stratigraphy of Late Precambrian tillites near Kapp Lyell, Spitsbergen. M.S. thesis, University of Wisconsin-Madison. 115 pp.

Kowallis, B. J. \& Craddock, C. 1984: Stratigraphy and structure of the Kapp Lyell diamictites (upper Proterozoic), Spitsbergen. Bulletin Geological Society of America 95, 1293-1302.

Lehmann, U., Thiedig, F. \& Harland, W. B. 1978: Spitzbergen im Tertiär. Polarforschung 48, 120-138.

Livšic, Ju. Ja. 1974: Paleogene deposits and the platform structure of Svalbard. Norsk Polarinstitutt Skrifter 159. 51 pp.
Manum, S. B. \& Throndsen, T. 1986: Age of Tertiary Formations on Spitsbergen. Polar Research 4, 103-131.

Steel, R. J, \& Worsley, D. 1984: Svalbard's post-Caledonian strata-an atlas of sedimentary patterns and paleogeographic evolution. Pp. 109-135 in Spencer, A. M. (ed.): Petroleum geology of the north European margin. Graham \& Trotman, London.

Thiedig, F., Pickton, C. A. G., Lehmann, U., Harland, W. B. \& Anderson, H. J. 1979: Das Tertiär von Renardodden (östlich Kapp Lyell, Westspitzbergen, Svalbard). Mitteilungen aus dem Geologisch-Paläontologischen Institut der Universität Hamburg 49, 135-146.

Vonderbank, K. 1970: Geologie und Fauna der tertiären Ablagerungen Zentral-Spitzbergens. Norsk Polarinstitutt Skrifter 153. $120 \mathrm{pp}$.

Waddams, P. 1983: Late Precambrian resedimented conglomerates from Bellsund, Spitsbergen. Geological Magazine 120, 153-164. 